\title{
Elisabeth L. Engebretsen et William F. Schroeder, avec Hongwei Bao (éds.), Queer/Tongzhi China: New Perspectives on Research, Activism and Media Cultures, Copenhague, Nias Press, 2015, 274+xiii p.
}

\section{Tiantian Zheng}

\section{OpenEdition \\ Journals}

\section{Electronic version}

URL: http://journals.openedition.org/chinaperspectives/7369

DOI: 10.4000/chinaperspectives.7369

ISSN: 1996-4617

\section{Publisher}

Centre d'étude français sur la Chine contemporaine

\section{Printed version}

Date of publication: 1 June 2017

Number of pages: 87-87

ISSN: 2070-3449

\section{Electronic reference}

Tiantian Zheng, «Elisabeth L. Engebretsen et William F. Schroeder, avec Hongwei Bao (éds.), Queer/ Tongzhi China: New Perspectives on Research, Activism and Media Cultures, ", China Perspectives [Online], 2017/2 | 2017, Online since 01 June 2017, connection on 24 September 2020. URL : http:// journals.openedition.org/chinaperspectives/7369; DOI : https://doi.org/10.4000/chinaperspectives. 7369

This text was automatically generated on 24 September 2020.

(C) All rights reserved 


\section{Elisabeth L. Engebretsen et William F. Schroeder, avec Hongwei Bao (éds.), Queer/Tongzhi China: New Perspectives on Research, Activism and Media Cultures,}

Copenhague, Nias Press, 2015, 274+xiii p.

Tiantian Zheng

This edited volume collects works from activists, scholars, and artists from China and beyond to address the issue of social activism and community-building among the LGBTQ population in China. Employing diverse methodologies from disciplines such as anthropology, cultural and media studies, Chinese studies, literature, and sociology, this volume presents the voices and perspectives of LGBTQ artists, scholars, and activists who organise communities and disseminate ideas through myriad cultural venues such as documentary and online media platforms. In so doing, the volume demonstrates the polyvalent and sometimes interchangeable meanings and uses of terms such as tongzhi and queer, and the tensions between political activism and academic works.

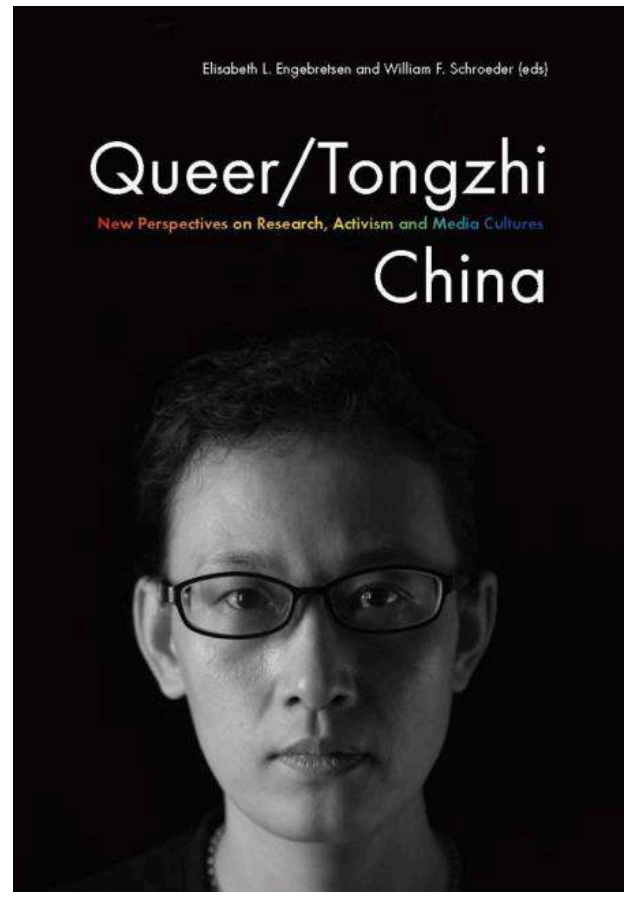

China Perspectives, 2017/2 | 2017 
2 The volume addresses various political challenges arising in research, teaching, and other activist practices on sexual and gender minorities in China. Contributors to the volume discuss political censorship, self-censorship, heavy scrutiny, and government control over their publication, teaching, academic work, research projects, and activist practices through online media and films. The tensions between the pressure to conform to local cultural and political norms and the desire to establish social activism and build a community produce a plethora of creative strategies to develop new discourses and platforms locally and globally.

3 The volume delves into the most prevalent strategy to engage in activism - popular media such as film, art, websites, and digital video. Contributors such as Popo Fan in Chapter 5 write about their experiences, goals, the essence of their work, the differences between their work and that of Western counterparts, and the reasons, cultural constraints, and government controls, and their reflexive accounts of the ways in which their media products advance LGBTQ politics. Chapter 2 examines the ways in which the bilingual website series Queer Comrades was created and politically censored, received local and global audiences and support, and successfully interconnected with global queer politics and culture. Chapter 3 analyses the significant role of digital films made by the famous filmmaker Cui Zi'en in helping build community and stage activism. An interview with Cui in Chapter 13 investigates the meanings of his career as a director, activist, community leader, and public intellectual.

4 Along the same line of inquiry, Chapter 8 examines the online literature of "boy love" the particular nature of this genre and the general disposition of its readers. In so doing, Yang and $\mathrm{Xu}$ interrogate "queer" boundaries and claim that a new type of grassroots feminism is arising from this online genre, and that it will reshape Chinese feminism and deepen the academic understanding of the category of gender. Chapter 9 discusses the presence of queer in the arena of Chinese popular music and situates it in the history of Chinese pop music. Wang argues that although government control has made queerness a kind of "superficial weirdness" in Chinese popular culture (p. 176), at least popular audiences are exposed to the presence of queer and experience a taste of queer.

5 The volume also presents ethnographic research conducted on and with the LGBTQ population. Chapter 7, based on the author's ethnographic research with same-sex attracted women (lala) in Beijing, argues that Chinese lala culture, increasingly informed by the West, runs the risk of changing its own local practices. Huang calls for a mechanism to maintain the local, culturally informed, flexible, and ambiguous social positions of gender roles. Chapter 11 narrates the author's ethnographic research with HIV activist organisations in Chengdu, and argues that institutional constraints, dependence on the government, and political censorship preclude the organisations from engaging in gay-related social advocacy. Instead, the organisations continue to focus on HIV/AIDS services for the government. In Chapter 12, Fu uses ethnographic research on the gay community in the northern city of Shenyang to argue that the market economy has unleashed spaces and platforms through which gay men gather together and develop their own identities, terminologies, and discourses.

This volume presents reflexive accounts of ethnographers' research with the LGBTQ community. Chapter 10 provides a self-reflexive account of a blurred "insider" and "outsider" relationship with same-sex attracted women (lala) in Shanghai. Kam discusses the ways in which her research with this community in Shanghai has 
connected with her memories and experiences in Hong Kong and China and offers her an opportunity to come out formally to readers and the academic community as a queer-identified researcher. Chapter 4 provides a self-reflexive account as a nonChinese researcher in the polyvalent approaches and meanings of activism and movement. Schroeder argues for a complex, nuanced, and multifaceted approach to activism and its role in knowledge production. Chapter 6 contextualises queer grassroots activism in interdisciplinary and transnational realms to demonstrate the local nuances and variations of Chinese tongzhi activism in appropriating Pride rhetoric and visibility strategies such as the use of urban space. Engebretsen argues that the diverse and nuanced strategies employed by queer grassroots activism in China have challenged the rigid Western model of queer movements for inclusion, justice, and freedom.

7 The volume contributes to the current literature on the LGBTQ population in China in its interdisciplinary approach and its presentation of diverse voices and perspectives of artists, scholars, and activists from China and beyond. Some conflicting arguments arising from the volume are to be answered and resolved by future pursuits. For instance, some chapters argue that ethnographic research on grassroots organisations shows their focus on health issues rather than on gay-related social advocacy or activism, whereas other chapters argue for a more multifaceted approach to activism that includes even a Saturday skate outing. That said, this volume should be welcomed by scholars who have an interest in gender, sexuality, LGBTQ, media studies, anthropology, and China studies.

\section{AUTHOR}

\section{TIANTIAN ZHENG}

Tiantian Zheng is Professor of Anthropology at the State University of New York, Cortland

(Tiantian.Zheng@cortland.edu). 